\title{
Development of an electronic controller for lettuce production in greenhouses
}

\section{Aldir Carpes Marques Filho' ${ }^{1}$, Jean Paulo Rodrigues ${ }^{2}$, Simone Daniela Sartorio de Medeiros ${ }^{3}$, Sergio Ricardo Rodrigues de Medeiros ${ }^{3}$}

\author{
${ }^{1}$ Universidade Estadual Paulista Júlio de Mesquita Filho, Campus Botucatu, Botucatu, São Paulo, Brasil. E-mail: \\ aldir.marques@gmail.com \\ ${ }^{2}$ Instituto Federal de Santa Catarina, Campus Florianópolis, Florianópolis, Santa Catarina, Brasil. E-mail: jeanpaulo@ifsc.edu.br \\ ${ }^{3}$ Universidade Federal de Santa Catarina, Campus Florianópolis, Florianópolis, Santa Catarina, Brasil. E-mail: \\ sisartorio@gmail.com, medeirossoft@gmail.com
}

Received: 28/10/2019; Accepted: 10/08/2020.

\begin{abstract}
The objective of this study was to develop an electronic controller for microclimate control in greenhouses, as well as to verify if the automated control system affects the productivity of two varieties of lettuce "Lactuca sativa". The control system was developed based on the Atmega 2560 and compatible transducers. An experimental field analysis was carried out over a production cycle for two lettuce varieties. The experimental results showed that the designed equipment worked according to the implemented programming algorithm. However, the ventilation, nebulization and shading actuators did not control environmental variables, due to under sizing. The irrigation process was correctly controlled throughout the experimental period. The electronic controller promoted increase in the productivity of lettuce varieties. There was increase of $28 \%$ in total fresh weight; $10 \%$ in stem diameter; 7 and $8 \%$ in height gain and average diameter, respectively.
\end{abstract}

Keywords: Arduino, lettuce, plant physiology, micro-controllers.

\section{Desenvolvimento de um controlador eletrônico para produção de alfaces em casas de vegetação}

\section{RESUMO}

Objetivou-se com o presente trabalho desenvolver um controlador eletrônico para monitoramento e controle microclimático em casas de vegetação, bem como verificar se o sistema de controle automatizado afeta a produtividade de duas variedades de alface "Lactuca sativa". O sistema foi desenvolvido com base no microcontrolador Atmega 2560 e em transdutores compatíveis. Foi realizada análise experimental de campo ao longo de um ciclo produtivo para duas variedades de alface. Os resultados experimentais indicaram que o equipamento projetado funcionou de acordo com o algoritmo implementado, porém os atuadores de ventilação, nebulização e sombreamento não controlaram as variáveis ambientais, por motivo de subdimensionamento. $\mathrm{O}$ processo de irrigação foi corretamente controlado ao longo do período experimental. O controlador eletrônico promoveu o aumento de produtividade das variedades de alface em casa de vegetação. Verificou-se o incremento de $28 \%$ em massa fresca total; $10 \%$ em diâmetro do colmo; 7 e $8 \%$ em ganho de altura e diâmetro médio, respectivamente.

Palavras-chave: Arduino, alface, fisiologia vegetal, microcontroladores. 


\section{Introduction}

The main advantage of producing in greenhouses is the possibility of growing plants in adverse climates, offering ideal environmental conditions for crops (Vatari et al., 2016).

Ishikava and Figueiredo (2011) stated that the lack of skilled labor is a problem for production in greenhouses, limiting the expansion of production. Thus, prototyping platforms are a low-cost alternative for automation of agricultural production processes.

The increasing demand for efficient and accessible electronic systems has motivated research using prototyping platforms (Bajer and Krejkar, 2015; Mekki et al., 2015; Wishkerman and Wishkerman, 2017). Studies have used the Arduino platform to create agricultural control systems. The main motivation of such projects is versatility of applications and their low cost.

Fuentes et al. (2014) confirmed the feasibility of using free software and hardware platforms to obtain field data and monitor photovoltaic systems. Nugroho et al. (2016) reported the application of development platforms to monitoring and controlling systems in rural areas, highlighting the potential of applying them horticulture.

To facilitate and improve the process, Vatari et al. (2016) evaluated the operation of two greenhouse control systems. The authors reported innovations in data acquisition using sensors and storage of values in clouds, basing the study on the concept of internet of things (IoT). The authors proved that electronic technology has been fostering precision agriculture (Wishkerman and Wishkerman, 2017; Santos et al., 2018; Mazon-Olivo et al., 2018; Zhou et al., 2018).

This work developed an electronic controller for monitoring and the microclimate control in greenhouses, and also for verifying if the automatic control system affects the productivity of two varieties of lettuce "Lactuca sativa".

\section{Material and Methods}

The electronic control environmental system followed the methodology proposed by Rozenfeld et al. (2015). A prototype was assembled. It consisted of an Arduino ATmega2560 control board (Arduino, 2018) fixed to a metal case with eight push-down buttons and an LCD display (20x4, twenty characters and four lines) (Figure 1a). The controller was equipped with a Real Time Clock (RTC) system, a Secure Digital (SD) cardholder, and a board with eight 250V/10A output relays. The inputs of the system were electronic transducers (Figure 1b) compatible with the controller. The transducers were three DHT-22 thermo-hygrometers containing three FC-28 soil moisture sensors and three
LDR (Light Dependent Resistor) global radiance sensors arranged in three 40-mm PVC supports (Polyvinyl Chloride) (Figure 1c).

The DHT22 sensors (Aosong, 2015) collect temperature data based on an NTC-type thermistor and a capacitive element. The scale for relative humidity is 0 $100 \%( \pm 2-5 \%)$ and for temperature -40 to $80^{\circ} \mathrm{C}( \pm 0.5$ $\left.1.0^{\circ} \mathrm{C}\right)$.

The estimation of soil moisture performed by the FC28 sensor and global radiation performed by the LDR sensor (in percentage) was a low investment strategy, although results obtained by Abdel-Ghany (2011) have demonstrated the importance of converting radiation into latent and sensitive heat and its relationship with plant respiratory rates. However, radiation sensors are expensive and secondary for small and medium-scale cultivation. Figure 2 shows the circuit diagram of the system.

The controller setting was carried out in Processing/C++. Information on ideal environmental conditions for lettuce crops at each stage of development was consulted from the literature. From 0 to 20 days after daytime transplanting, the values programmed were ideal temperature $\left(20-25.7^{\circ} \mathrm{C}\right)$, ideal relative air humidity (76.5-93.5\%), and ideal soil moisture (62-85\%) (Cermeño, 1990). The operating chart of the controller is described in Figure 3.

The evaluation of performance of the electronic controller was performed by a controlled environment experiment in Biguaçu/SC, Brazil (27 46'42" S, $\left.48^{\circ} 72^{\prime} 42^{\prime \prime} \mathrm{W}\right)$. The soil was classified as a red yellow Argisol with a loamy texture, according to Santos et al. (2013). Soil analysis and correction were performed according to the values for lettuce cultivation recommended by Yuri et al. (2016).

The experiment was performed in two protected environments (A1 and A2) using a high arch tunnel model with a height of $2.75 \mathrm{~m}$ and a total area of $50 \mathrm{~m}^{2}$ each $(5 \times 10 \mathrm{~m})$. PVC cover with 150 micrometers was used, in full coverage, without side openings and without artificial shading.

In the A1 greenhouse, ventilation, irrigation, misting and shading actuators were installed. In the A2 environment, only the irrigation system with manual operation was installed. One irrigation was performed early in the morning and two irrigations were performed in early and late afternoon. Manual irrigation is the standard procedure adopted by the non-automated production model.

For the ventilation actuator, a dwt220R fan was used. It has $80 \mathrm{~W}$ of power, $0.6 \mathrm{~m}$ of propeller diameter, and average airflow of $0.98 \mathrm{~m}^{3} \mathrm{~s}^{-1}$. For the activation of irrigation and misting systems, electro valves with a nominal diameter of $12.5 \mathrm{~mm}$ were used; the maximum flow rate was $20 \mathrm{~L} \cdot \mathrm{min}^{-1}$ and the power was $5 \mathrm{~W}$. The 
irrigation model used in the A1 and A 2 environments was direct sprinkler. It is composed of two central branches, ten meters long each, in a micro-perforated hose (Figure 4a). Weed control was performed using traditional methods of weeding and manual removal at 10, 15 and 20 days after transplanting (DAT).

A meteorological shelter (MS) was installed in front of the greenhouse to protect the electronic control system and data acquisition systems. The meteorological shelter was built using Pinus sp. wood and painted with a white acrylic paint. It has $1.10 \mathrm{~m}$ of frontal width, $0.80 \mathrm{~m}$ of height, and $0.30 \mathrm{~m}$ of depth. The cover of the shelter was built using 4-mm fiber cement roof tiles with a slope of $50 \%$ (Figure 4b).

In the field experiment, the biometric characteristics of two lettuce varieties, cv. Lucy Brown and cv. Vanda, were evaluated in environments with and without automation, respectively (Figure $4 \mathrm{c}$ ). To evaluate the productivity of lettuce crops, the following biometric data were measured: total plant diameter (PD), total plant height (PHe), stem diameter cut $1 \mathrm{~cm}$ from the soil (SD), and total fresh mass (TFM).
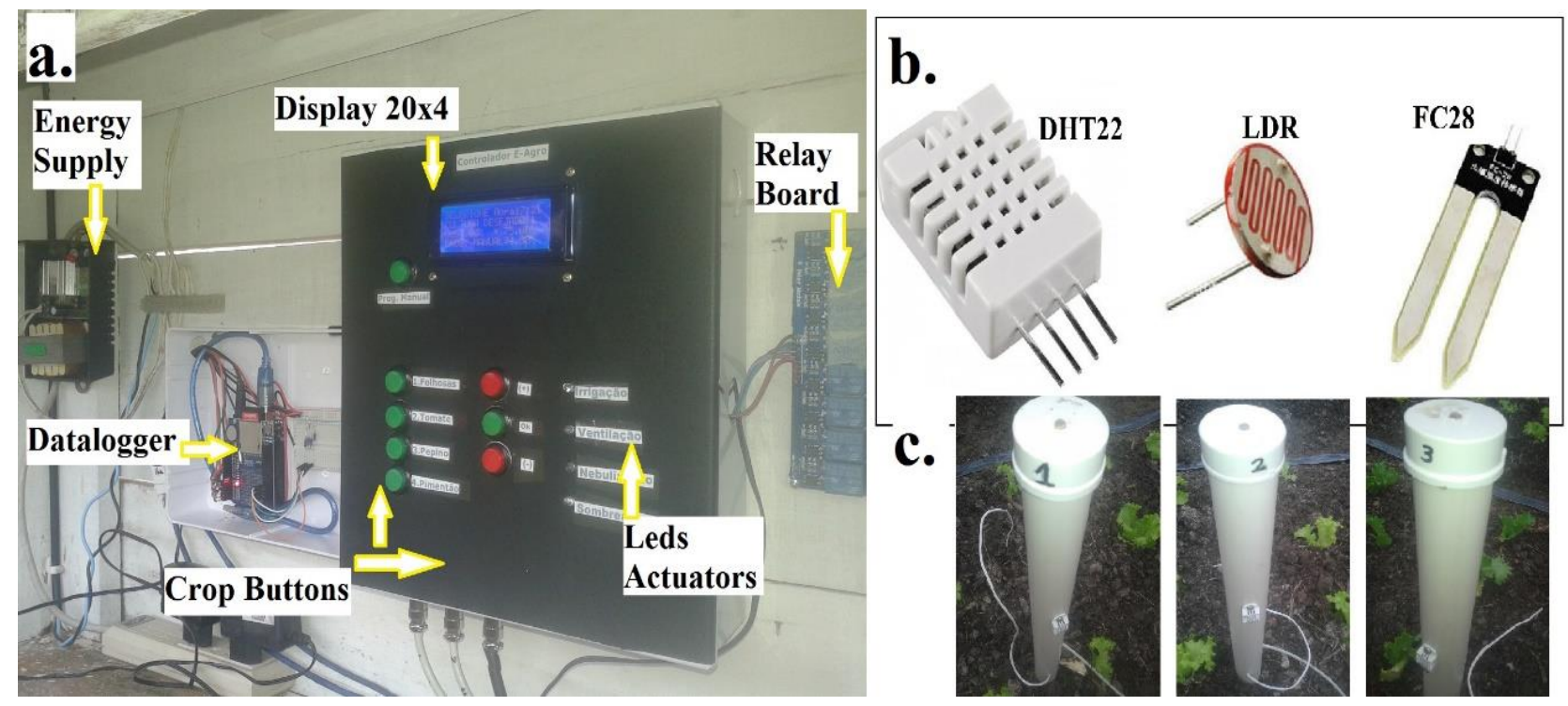

Figure 1. a.Controller case and access buttons; b. Transducers; c. PVC tower for data collection within crop area

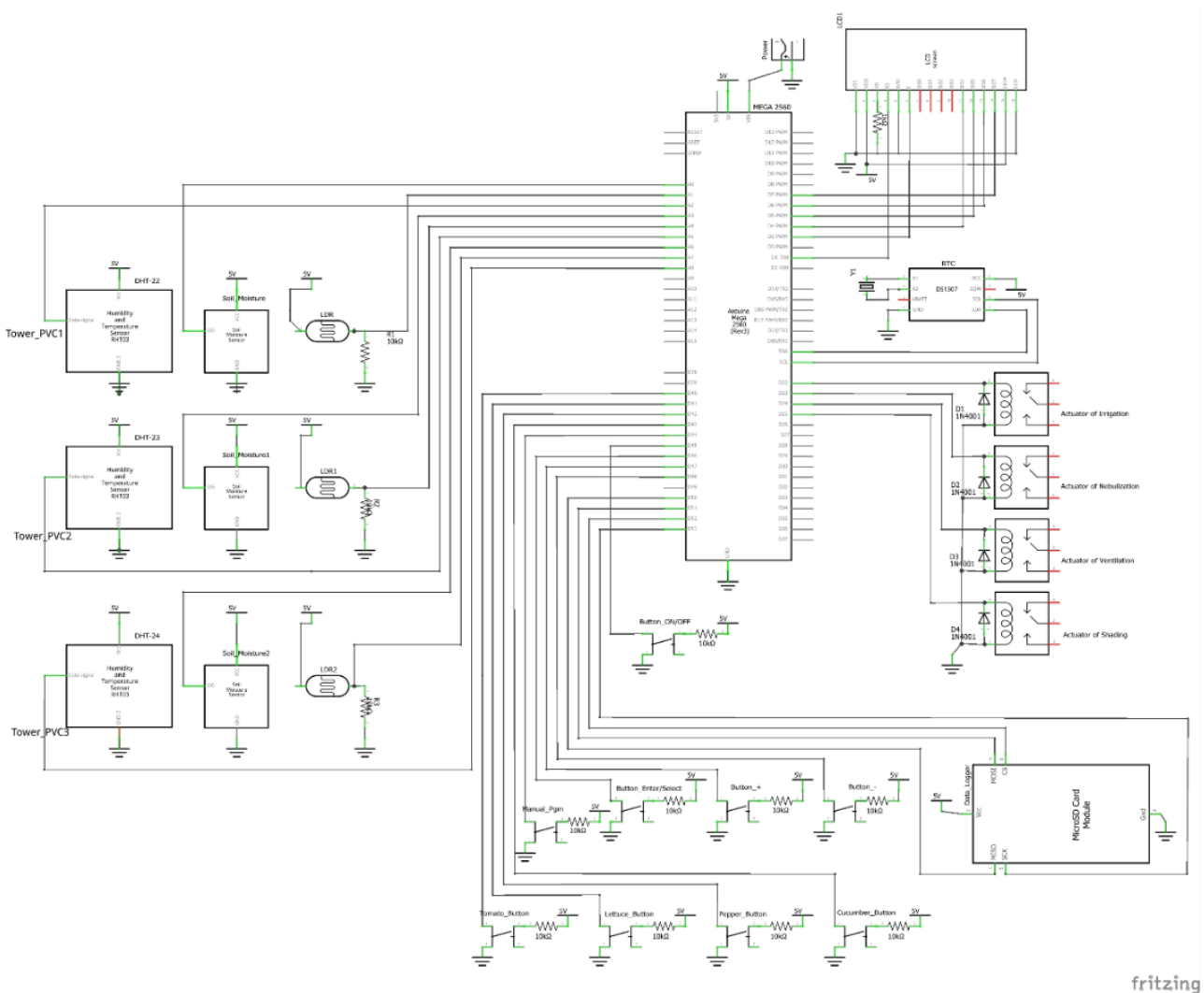

Figure 2. Schematic diagram of the electronic controller for greenhouses. 


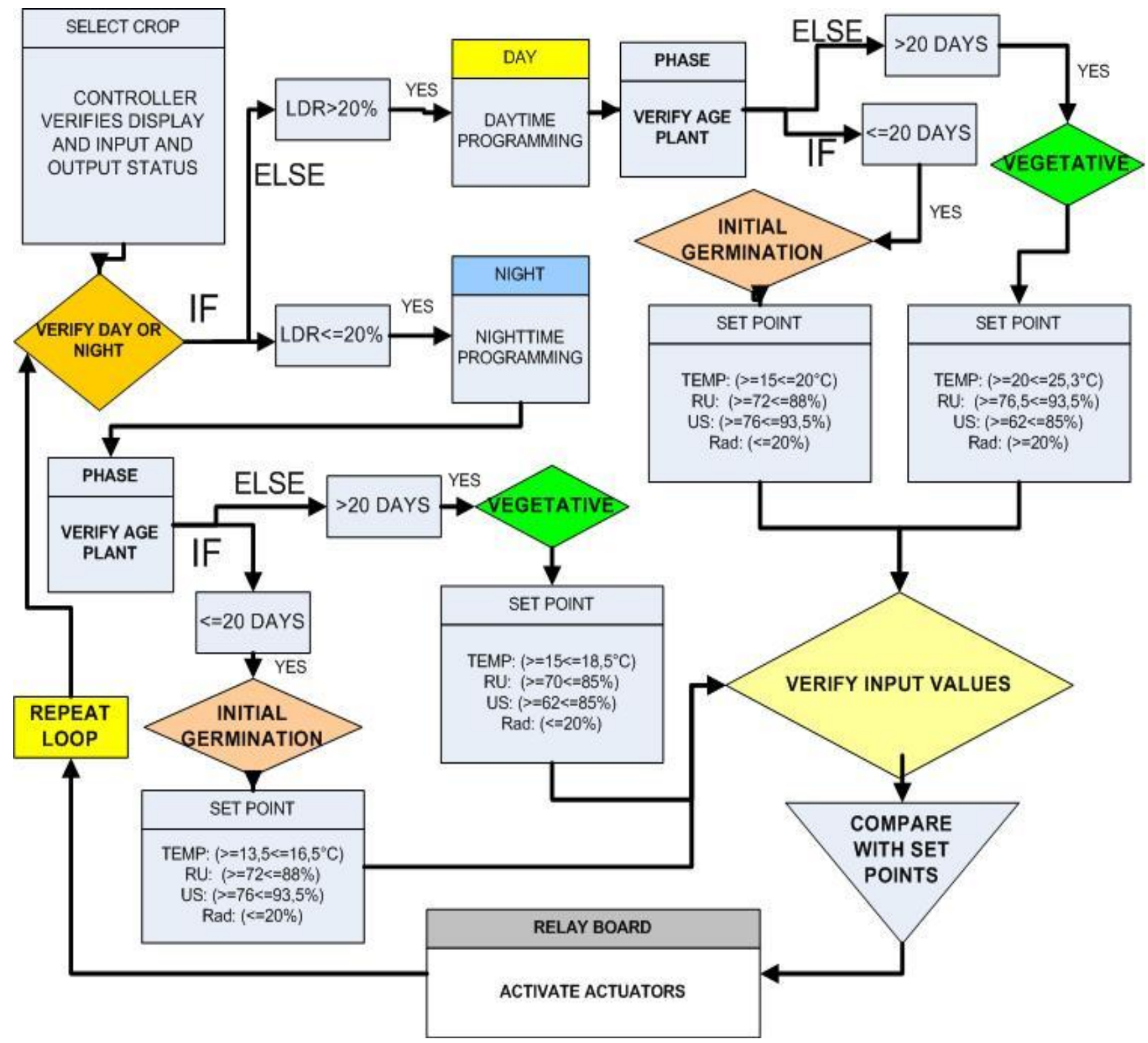

Figure 3. Chart of the system for lettuce cultivation (Lactuca sativa $\mathrm{L}$.)

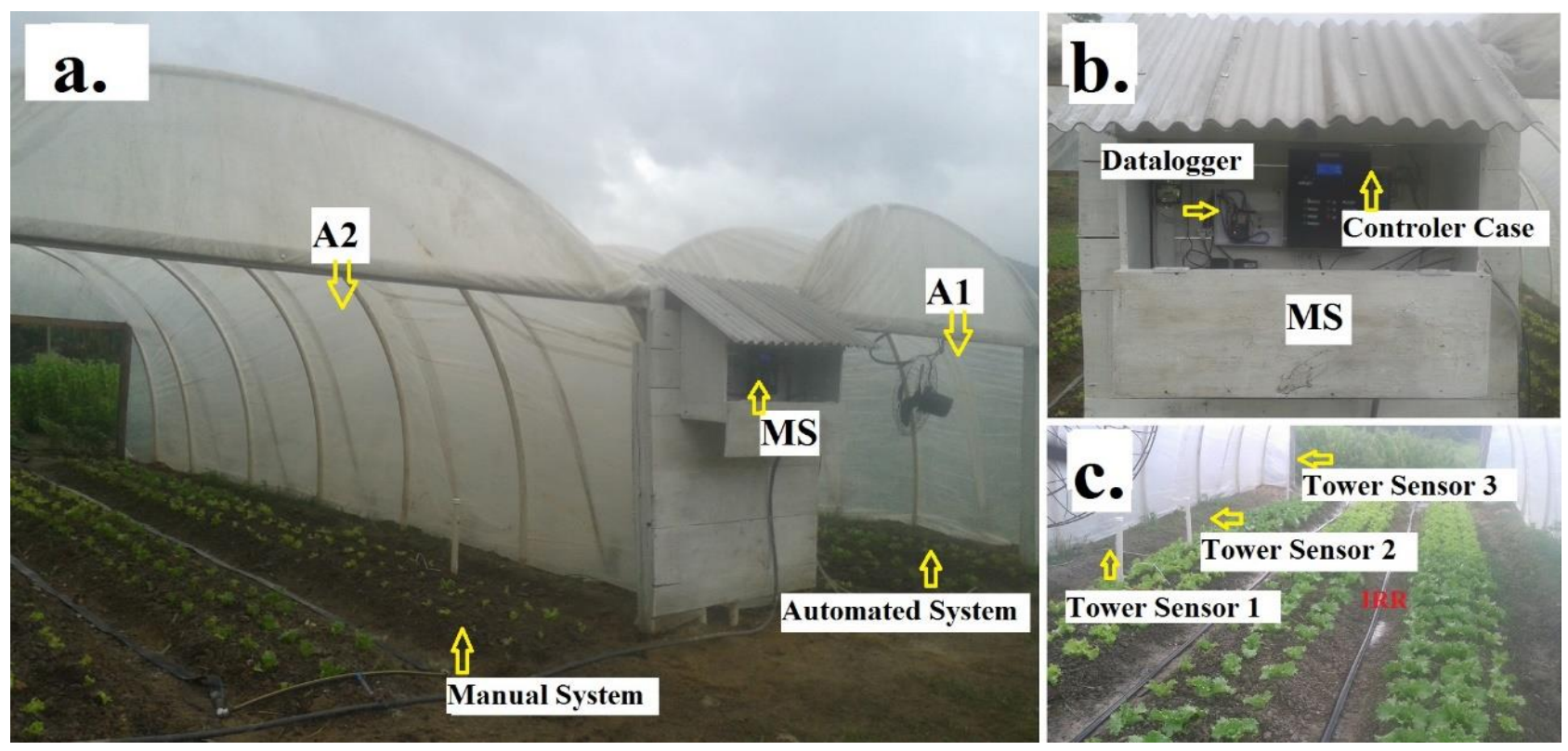

Figure 4. a. Greenhouses A1 and A2; b. Meteorological protection for electronic systems; c. Interior of A1 with the installed experiment. 
Inside $\mathrm{A} 1$ and $\mathrm{A} 2$, three identical plant beds were built $(1 \times 10 \mathrm{~m}$ long, $0.2 \mathrm{~m}$ high). The seedlings were produced in expanded polyethylene trays containing 128 cells using commercial substrate, maintaining only one seedling per cell in a nursery for 19 days.

The system operation was monitored through data stored on a SD card attached to the controller. Information on activation of actuators and sensors was obtained in real time, as well as the date and time of each event; thus constructing an auxiliary database for future decision-making.

The harvest was performed 21 DAT. Eight plants were removed from the central range of plant beds per experimental plot in each evaluation, excluding the plants of the extremities because of border effects.

The biometric variables PD and PHe were measured still in the field using a metallic graduated ruler. Afterwards, plants were harvested $1 \mathrm{~cm}$ from the soil using cutting shears. The SD was measured using a pachymeter, and the TFM was measured using a digital precision scale.

The intervals lasted 24 hours and the measurements were performed hourly. The experiment was completely randomized in a $2 \times 2$ factorial design with six replications. The first factor comprised the cultivation environments $\mathrm{A} 1$ and $\mathrm{A} 2$ and the second factor comprised the cultivars V1 and V2. The response variables were submitted to analysis of variance and, when necessary, a Tukey test was applied at a 5\% significance level. All statistical analyses were performed using the software R (2018).

\section{Results and Discussion}

The controller presented satisfactory response throughout the experimental period. It performed the monitoring and activation of actuators according to the programming proposed. Data were stored on a SD card and later processed using the appropriate software. Nugroho et al. (2016) made use of a SD card for data storage for data acquisition and monitoring systems and obtained positive results in a region with poor internet quality.

During the first days of operation, the environmental parameters of temperature, relative humidity and radiation were not in the comfort range for the crop for a few hours, even when the actuators were activated. The radiation exceeded this parameter in some days during a first and second phase, and this event was correctly detected by the control system (Figure 8). On the first day of data collection, there was great variation in the values of temperature and relative air humidity (Figure 5 and 6), which triggered the activation of ventilation and misting actuators for a total of six and nine hours, respectively.
Our ventilation actuators have been undersized for the greenhouse.

On the second day, the relative humidity remained below the programmed value, even with the nebulizer actuator turned on for 15 hours. This fact clearly demonstrates that the nebulization system was incompatible for the constructive characteristics of the greenhouse. In the third and fourth days of the experiment, temperature, and radiation (Figure 5 and 8) were within the programmed value, with the activation of only three hours of misting in a 48-hour interval.

The main behavior is the ineffectiveness of the ventilation and misting systems for controlling the process, even when the controller performed the appropriate activation according to schedule. The functioning of the control system was successful. However, the actuators were not efficient. In some moments, critical levels of humidity and temperature were reached, as on 13-16 DAT peaks of temperature and relative humidity were well below expectations. Even though it did not completely control the process, the control system adjusted the temperature and relative humidity of the air discreetly, with better values for A1.

The best controlled process was irrigation. Figure 7 shows the soil moisture at A1 permanently within the ideal range. In A2 we found significant variations in soil moisture, which was decisive in the final productivity results. Our findings allow us to state that the greatest advantage found in the experiment was the correct control of water availability for the roots. The sprinkled water also affected the air temperature and humidity in A1.

The luminosity obtained with low-cost sensors of the LDR type, does not allow to obtain reliable information, but provides an approximation of the real parameter for shading control (Figure 8). Hassanien and Ming (2017), working with translucent photovoltaic panels, stated that a moderate shading has little influence on lettuce productivity and can be an alternative to generate electrical energy for the system.

The means of total fresh mass, plant diameter, plant height, stem diameter, and total productivity are shown in Table 1. For all variables, the interaction between factors was not significant $(p>0.05)$. Plant diameter differed between environments. A1 plants had larger diameters, indicating a greater vegetative development possibly provided by adequate water supply and environmental conditions close to ideal. Yuri et al. (2016) stated that lettuce is a fast-cycle crop. It is very demanding in nutrients at its final development phase (after approximately 20 to 30 days of planting). The authors emphasized the importance of nutrition during this period and adequate water availability for correct absorption of minerals. 


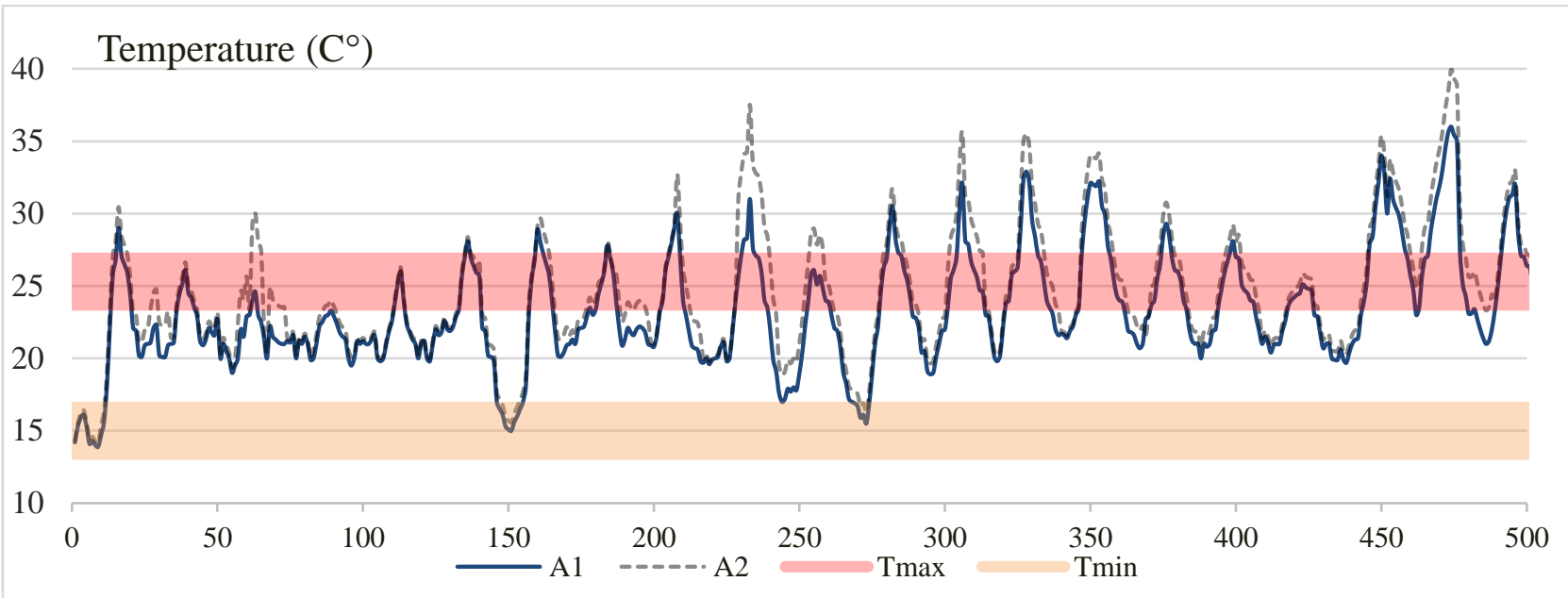

Figure 5. Internal temperature in A1 and A2 during the experimental period (504 hours). The red and green areas determine the range of the controlled variable.

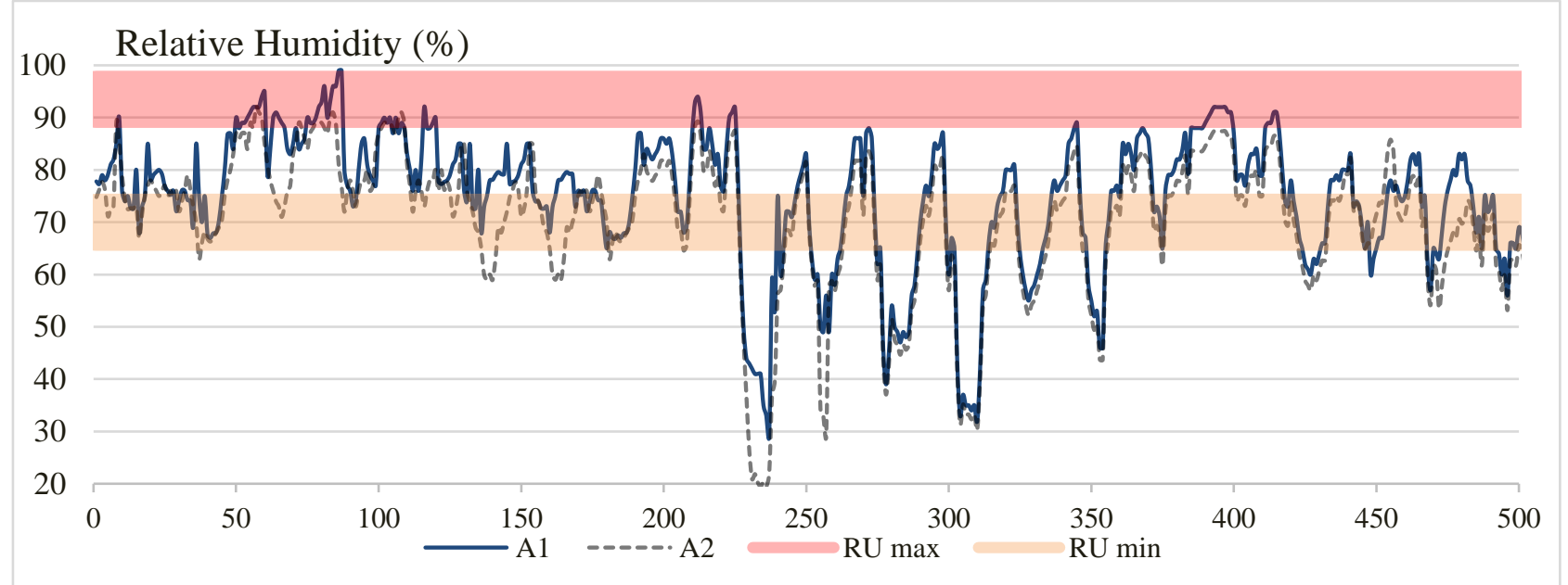

Figure 6. Internal Relative Humidity in A1 and A2 during the experimental period (504 hours). The red and green areas determine the range of the controlled variable.

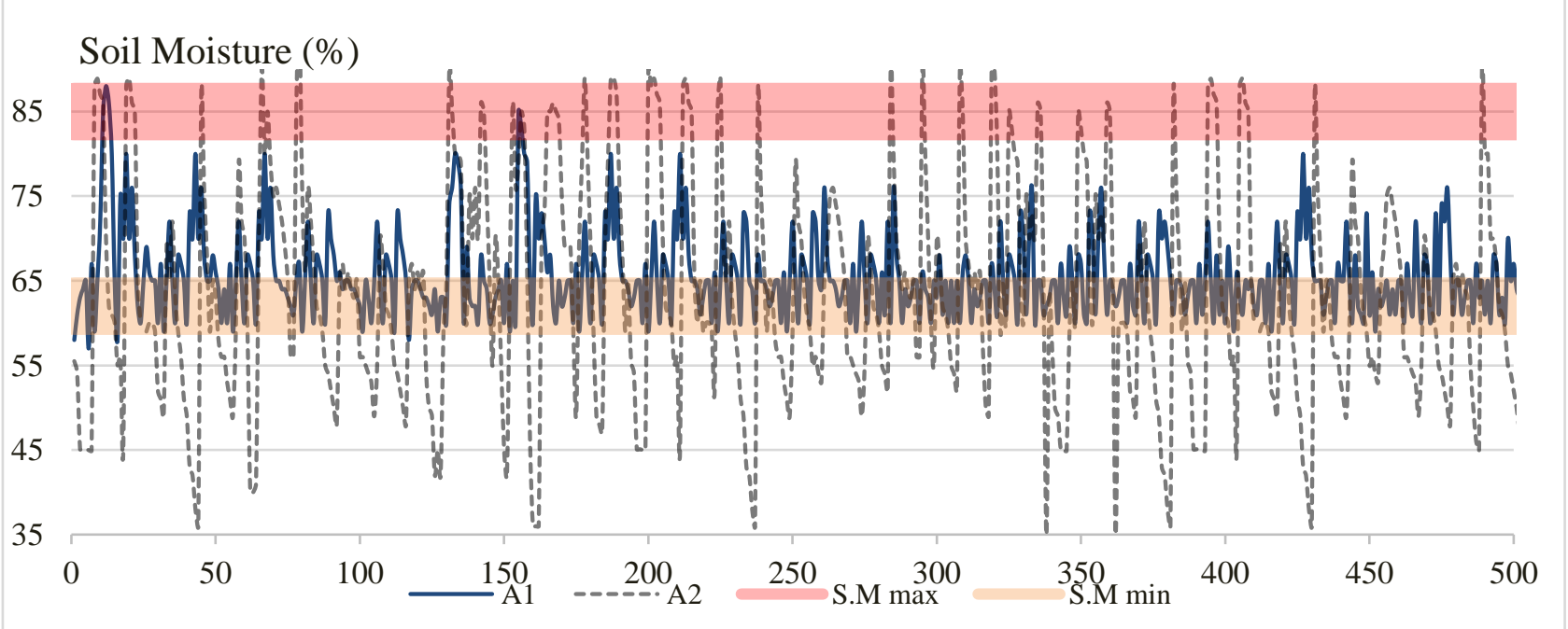

Figure 7. Soil moisture in A1 and A2 during the experimental period (504 hours). The red and green areas determine the range of the controlled variable. 


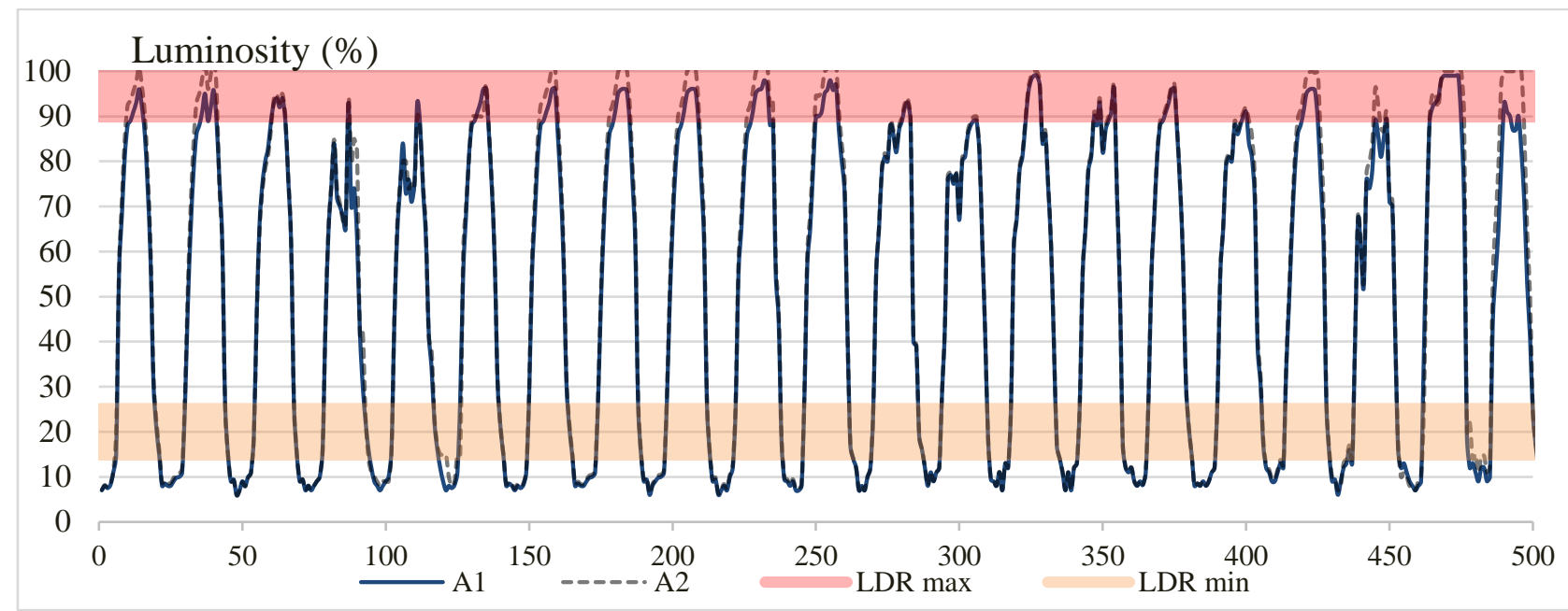

Figure 8. Luminosity (LDR) in A1 and A2 during the experimental period. The red and green areas determine the range of the controlled variable.

Table 1. Tukey test results (5\% probability) for biometric characteristics of two varieties of Lactuca sativa L., A1 and A2 crops

\begin{tabular}{ccccc}
\hline Factor level & $\begin{array}{c}\text { Plant diameter } \\
(\mathbf{c m})\end{array}$ & $\begin{array}{c}\text { Plant height } \\
(\mathbf{c m})\end{array}$ & $\begin{array}{c}\text { Total fresh mass } \\
(\mathbf{k g})\end{array}$ & $\begin{array}{c}\text { Stem diameter } \\
(\mathbf{c m})\end{array}$ \\
\hline $\mathbf{A 1}$ & $35.20(1.56) \mathbf{A}$ & $25.71(2.69) \mathbf{A}$ & $0.18(0.04) \mathbf{A}$ & $1.33(0.09) \mathbf{A}$ \\
$\mathbf{A 2}$ & $32.33(1.86) \mathbf{B}$ & $23.92(2.07) \mathbf{A}$ & $0.14(0.03) \mathbf{B}$ & $1.20(0.10) \mathbf{A}$ \\
\hline cv. Lucy Brown & $34.25(1.83) \mathbf{A}$ & $24.29(2.11) \mathbf{A}$ & $0.18(0.03) \mathbf{A}$ & $1.28(0.10) \mathbf{A}$ \\
cv.Vanda & $32.90(2.63) \mathbf{A}$ & $25.33(2.89) \mathbf{A}$ & $0.14(0.03) \mathbf{B}$ & $1.25(0.13) \mathbf{A}$ \\
\hline
\end{tabular}

* Means followed by the same letter in columns do not differ by Tukey test at $5 \%$ probability.

The biometric variables plant height and stem diameter did not differ between environments possibly because these characteristics were not responsive to stimuli. This also occurred for plant diameter, plant height and stem diameter for both lettuce varieties (Table 1). In a study on fertilization and light levels, Gonçalves et al. (2017) reported plant height and stem diameter as mostly affected. Total mass and height were affected by the etiolation process.

The variable total fresh mass presented significant differences between varieties and between environments. The statistical difference between the varieties was possibly due to different vegetative conformations. However, the difference between environments is interesting; it is possibly related to the automation in A1.

For Marenco and Lopes (2013), stress due to lack of water in the soil stimulates the closure of stomata, which hinders the absorption of carbon dioxide and affects the growth of plant tissues. Thus, plants under water stress have lower growth rates at some point in their cycle compared to plants under adequate water availability at all development stages. Yuri et al. (2016) stated that adequate nutrition of lettuce increases total productivity and guarantees a greater income for the producer.

Data of total fresh mass allow concluding that productivity per area is higher for the protected crop with automation than for the protected crop with manual operation (Table 1). In percentage terms, the mean of total fresh mass of the two varieties, in the A1 environment was $28 \%$ higher than in the A2 environment. These data are similar to Santos et al. (2018), who obtained gains of $17.9 \%$ in leaf development and $14.29 \%$ in arugula cultivation by using an electronic monitoring system.

Researchers have successfully developed new systems of wireless communication between sensors and control systems (Mazon-Olivo et al., 2018; Oliveira Junior et al., 2018). Therefore, a future improvement of the system developed in this study could be the addition of a wireless network card to the PVC supports. It would facilitate the installation process and reduce the risk of damage to the system. Zhou et al. (2018), studying response of soybeans to saline stress, used image analysis to correlate this response with plant physiology, and obtained good correlation results. González-Esquiva et al. (2017) used low-cost cameras for environmental monitoring and obtained promising results. This opens the way to new research on environmental monitoring based on pictures.

\section{Conclusions}

The control system developed increased the lettuce productivity in greenhouses. We found $28 \%$ increase in fresh mass, $10 \%$ in stem diameter, $7 \%$ in plant height and $8 \%$ in average plant diameter. 
The control algorithm maintained the actuation of the actuators in all stages of the research. The irrigation variable was successfully controlled, and the soil moisture remained in appropriate ranges throughout the experimental period.

\section{Bibliographic References}

Abdel-Ghany, A.M., 2011. Solar energy conversions in the greenhouses. Sustaintable systems and society, 1(4), 219-226.

Aosong, 2015. AM2302 Digital output relative humidity and temperature sensor.

https://www.sparkfun.com/datasheets/Sensors/Temperature/D HT22.pdf (accessed July 17, 2020).

Arduino, 2018. What is Arduino?

https://www.arduino.cc/en/Guide/Introduction (accessed

August 20, 2018).

Bajer, L., Krejcar, O., 2015. Design and realization of low cost control for greenhouse environment with remote control. Czech Republic, Internacional Federation of automatic control, 48(4), 368-373.

Cermeño, Z.S., 1990. Estufas instalação e manejo, second ed. Lisboa, Litexa.

Fuentes, M., Vivar, M., Burgos, J.M., Aguilera, J., Vacas, J.A., 2014. Design of an accurate, low-cost autonomous data logger for PV system monitoring using Arduino ${ }^{\mathrm{TM}}$ that complies with IEC standards. Solar Energy Materials e Solar Cells, 130, 529543.

Gonçalves, E.D.V., Dartora, J., Mendonça, H.F., Rissato, B.B., Dildey, O.D.F., Roncato, S., Santana, J.C., Klosowski, E.S., Echer, M.M., Tsutsumi, C.Y., 2017. Crescimento e produtividade de cultivares de alface em ambiente protegido com e sem tela termorrefletora. Scientia Agraria Paranaensis, 16(2), 193-199.

González-Esquiva, J.M., Oates, M.J., García-Mateos, G., Moros-Valle, B., Molina-Martínez, J.M., Ruiz-Cannales, A., 2017. Development of a visual monitoring system for water balance estimation of horticultural crops using low cost cameras. Computers and Eletronics in Agriculture, 141, 15-26.

Hassanien, R.H.E., Ming, L., 2017. Influences of greenhouseintegrated semi-transparent photovoltaics on microclimate and lettuce growth. International Journal of Agricultural and Biological Engineering, 10(6), 11-22.

Ishikava, S.M., Figueiredo, G., 2011. Olerícolas para cultivo em ambiente protegido. Revista Casa da Agricultura, 14(2), 2426.

Marenco, R.A., Lopes, N.F., 2013. Fisiologia Vegetal: fotossíntese, respiração, relações hídricas e nutrição mineral, terceira ed. UFV, Viçosa.
Mazon-Olivo, B., Hernández-Rojas, D., Maza-Salinas, J., Pan, A., 2018. Rules engine and complex event processor in the context of internet of things for precision agriculture. Computers and Electronics in Agriculture, 154, 347-360.

Mekki, M., Abdallah, O., Amin, M.B.M., Eltayeb, M., Tafaoul, A., Babiker, A., 2015. Greenhouse monitoring and control system based on wireless sensor network. International Eletronics and Embedded Systems Engineering. IEEE, Sudan, 384-387.

Nugroho, A.P., Okayasu, T., Hoshi, T., Inoue, E., Hirai, Y., Mitsuoka, M., Sutiarso, L., 2016. Development of a remote environmental monitoring and control framework for tropical horticulture and verification of its validity under unstable network connection in rural área. Computer and eletronics in agriculture, 124, 335-339.

Oliveira Junior, A.J., Souza, S.R.L., Cruz, V.F., Vicentin, T.A., Glavina, A.S.G., 2018. Development of an android APP to calculate thermal comfort indexes on animals and people. Computers and Electronics in Agriculture, 151, 175-184.

R Core Team, 2018. R: A language and environment for statistical computing. R Foundation for Statistical Computing, Vienna, Austria.

Rozenfeld, H., Forcellini, F.A., Amaral, D.C., Toledo, J.C., Silva, S.L., Alliprandini, D.H., Scalice, R.K., 2015. Gestão de desenvolvimento de Produtos: uma referência para melhoria do processo, primeira ed. São Paulo, Saraiva.

Santos, H.G., Jacomine, P.K.T., Anjos, L.H.C., Oliveira, V.A., Lumbreras, J.F., Coelho, M.R., Almeida, J.A., Cunha, T.J.F., Oliveira, J.B., 2013. Sistema brasileiro de classificação de solos, terceira ed. Brasília, Embrapa.

Santos, U.J.L., Pessin, G., Costa, C.A., Rigui, R.R., 2018. AgriPrediction: Aproactive internet of things model to anticipate problems and improve production in agricultural crops. Computer and Eletronics in Agriculture, 161, 202-213.

Vatari, S., Bakshi, A., Thakur, T., 2016. Green house by using IOT and cloud computing. Internacional Conference on Recent Trends in Electronics, Information and Communication Technology. IEEE, India, 246-250.

Wishkerman, A., Wishkerman, E., 2017. Application note: A movel low cost open-source LED system for microalgae cultivation. Computers and Electronics in Agriculture, 132, 5662.

Yuri, J.E., Mota, J.H., Resende, G.M., Souza, R.J., 2016. Nutrição e adubação da cultura da alface, in: Prado, R.M., Cecílio Filho, A.B. (Ed.). Nutrição e adubação de hortaliças. Jaboticabal, FCAV, p. 559-577.

Zhou, J., Chen, H., Zhou, J., Fu, X., Ye, H., Nguyen, H.T., 2018. Development of an automated phenotyping platform for quantifying soybean dynamic responses to salinity stress in greenhouse environment. Computers and Electronics in Agriculture, 151, 319-330. 